\title{
Clostridium difficile-associated diarrhea: Predictors of severity in patients presenting to the emergency department
}

\author{
Christopher N Andrews MD ${ }^{1}$, Janet Raboud $\mathrm{PhD}^{2}$, Barry O Kassen MD FRCPC ${ }^{1}$, Robert Enns MD FRCPC ${ }^{3}$
}

CN Andrews, J Raboud, BO Kassen, R Enns. Clostridium difficile-associated diarrhea: Predictors of severity in patients presenting to the emergency department. Can J Gastroenterol $2003 ; 17(6): 369-373$.

OBJECTIVE: Experiences with Clostridium difficile-associated diarrhea (CDAD) were reviewed to determine predictors of severity in patients presenting from the community.

METHODS: All patients admitted to two hospitals over 4.5 years with a primary diagnosis of CDAD were reviewed. Patients requiring a hospital stay of greater than 14 days, colectomy, intensive care unit admission or who died were classified as 'severe CDAD' and compared with the remainder of the patients (termed 'mild CDAD').

RESULTS: One hundred fifty-three patients (mean age $63.4 \pm 20.5$ years, range 21 to $93,64.7 \%$ female) were reviewed. Forty-four per cent of the patients had community-acquired CDAD, and the remainder had hospital-acquired disease. There were 44/153 (28.8\%) patients with severe CDAD, of which 10/153 (6.5\%) died. The severe group had more patients over 70 years old ( $75 \%$ versus $43 \%$ in the mild group, OR 3.09, CI 1.81-8.63, $\mathrm{P}<0.001)$ and had more comorbid disease (median two major organ systems affected [range zero to five] versus one [range zero to four] in the mild group, OR 1.52 , CI 1.27-2.65, $\mathrm{P}<0.05)$. Patients with recurrent CDAD were more likely to have severe CDAD (12/44 versus $10 / 109$ in the mild group, OR 4.10, CI 1.47-9.40, P<0.01).

CONCLUSION: Age over 70 years, comorbid illness and CDAD recurrence are significant risk factors for severe disease and a poor outcome in patients admitted to hospital for CDAD.

Key Words: Antibiotics; Clostridium difficile; Diarrhea; Pseudomembranous colitis; Risk factors
La diarrhée associée au Clostridium difficile : Les prédicteurs de gravité chez les patients qui se présentent à l'urgence

OBJECTIF : L'expérience relative à la diarrhée associée au Clostridium difficile (DACD) a été examinée afin d'établir les prédicteurs de gravité chez les patients qui arrivent de la collectivité.

MÉTHODOLOGIE : Tous les patients hospitalisés dans deux établissements au cours d'une période de 4,5 ans ayant reçu un diagnostic primaire de DACD ont été passés en revue. Les patients hospitalisés pendant plus de 14 jours, ayant subi une colectomie, ayant été admis à l'unité de soins intensifs ou qui sont décédés ont été classés comme souffrant d'une « DACD grave » et ont été comparés au reste des patients (atteints d'une «DACD bénigne ").

RÉSULTATS : Cent cinquante-trois patients (âge moyen de $63,4 \pm 20,5$ ans, fourchette de 21 ans à 93 ans, dont 64,7\% étaient des femmes) ont été étudiés. Quarante-quatre pour cent des patients souffraient d'une DACD non nocosomiale, et les autres, d'une DACD nocosomiale. On a recensé $44 / 153$ patients $(28,8 \%)$ atteints d'une DACD grave, dont 10/153 (6,5\%) sont décédés. Le groupe atteint de la forme grave comptait plus de patients de plus de 70 ans ( $75 \%$ par rapport à 43 $\%$ au sein du groupe bénin, RR 3,09, IC 1,81 à 8,63, P<0,001) et de maladies comorbides (en moyenne, deux systèmes organiques importants étaient atteints [fourchette de zéro à cinq], par rapport à un [fourchette de zéro à quatre] au sein du groupe bénin, $\mathrm{RR} 1,52$, IC 1,27 à 2,65, P<0,05). Les patients atteints de DACD récurrente risquaient davantage de souffrir d'une DACD grave (12/144 par rapport à 10/109 dans le groupe bénin, RR 4,10, IC 1,47 à $9,40, P<0,01)$.

CONCLUSION : Avoir plus de 70 ans et souffrir d'une maladie comorbide ou d'une récurrence de DACD sont des facteurs de risque importants de maladie grave et d'issue négative chez les patients hospitalisés par suite d'une DACD. lostridium difficile-associated diarrhea (CDAD) is a com-
mon nosocomial infection typically acquired in hospital
following the disruption of normal colonic flora by antibiotic
use. It is estimated that over 300,000 new cases occur in US
hospitals each year (1-3). The most commonly offending
antibiotics include clindamycin, cephalosporins, ampicillin
and other penicillin derivatives (4-7). Other potential risk fac-
tors that predict development of hospital-acquired CDAD are
increased age, comorbid illness, malnutrition and immunosup-
pression $(2,4,8-11)$. The epidemiology of community-acquired
CDAD has been described, although not extensively studied
(12-15), and suggests that incidence and morbidity of CDAD in the community is much lower than in hospital. The mortality of community-acquired CDAD also appears to be less than that in hospital, but this may reflect an element of selection bias because the most severe community cases are admitted to hospital and may be included in hospital-acquired statistics.

It is unclear whether patients presenting to emergency departments with CDAD represent community- or institutionally acquired disease, and the severity and outcome of these cases are not known. Our main objective was to retrospectively determine if clinical and laboratory parameters exist that

${ }^{1}$ Departments of Medicine, Health Care and Epidemiology; ${ }^{2}$ Center for Health Evaluation and Outcome Sciences; and ${ }^{3}$ Division of Gastroenterology, St Paul's Hospital, University of British Columbia, Vancouver.

Correspondence and reprints: Dr Robert Enns, Division of Gastroenterology, Department of Medicine, University of British Columbia, St Paul's Hospital, \#300-1144 Burrard Street, Vancouver, British Columbia V6K-2A5. Telephone 604-688-7017, fax 604-689-2004, e-mail renns@interchange.ubc.ca 
predict the severity of the disease in these patients admitted to hospital with CDAD. Secondarily, we aimed to analyze the demographics, antibiotic usage and outcomes of patients admitted with CDAD.

\section{METHODS}

A computerized search of all discharge records databases at two large urban tertiary care hospitals (St Paul's and Vancouver General Hospital, Vancouver, British Columbia) was conducted. Charts from all admissions to hospital from January 1995 to July 1999 with a most responsible diagnosis of C difficile-related diarrhea (ICD-10 code 008.45) were identified and reviewed. The most responsible diagnosis is the main discharge diagnosis; that is, the main or primary cause for admission, as determined at the time of discharge. Only patients with a positive C difficile cytotoxin A stool enzyme-linked immunoassay (Triage Micro, Biosite Inc, USA) from an admission sample or unambiguous pseudomembranous colitis on lower gastrointestinal tract endoscopy were included. Patients presenting with symptoms other than $\mathrm{C}$ difficile-related disease, or who developed CDAD after admission to hospital, were excluded.

Once the stool toxin assay confirmed the diagnosis of CDAD, all patients were treated with either oral or intravenous metronidazole, or oral vancomycin. Many patients were started on therapy at the time of admission after stool samples were taken, including the majority of those who presented with recurrent CDAD. A proportion of patients received vancomycin in addition to metronidazole. Considerable variability existed as to the regimens of treatment, based on the patient's ability to take medications by mouth, previous CDAD treatment regimens and severity of illness.

Patients were grouped according to outcome. Patients with severe CDAD were defined as those requiring a hospital stay greater than 14 days, colectomy, intensive care unit admission or who died during the hospitalization. The remainder of the patients were termed mild CDAD.

Demographic variables (sex, age), preadmission variables (duration of diarrhea before admission, symptom score, bowel movements per day, previous CDAD diagnosis, number and type of antibiotics used in the 60 days before admission, comorbid disease), history of hospital-acquired CDAD and admission variables (admitting service, presence of fever, heart rate, white blood cell count, hemoglobin, and albumin level) were compared between severe CDAD and mild CDAD groups.

Community-acquired CDAD was defined as any patient presenting with CDAD who did not reside in a nursing home and who had not been hospitalized more than $24 \mathrm{~h}$ in the 60 days before admission, regardless of the timing of antibiotics. The remainder of the patients were designated hospital-acquired CDAD.

Due to the nature of retrospective reviews, information on other preadmission risk factors (eg, contact with infected patients or babies, visits to outpatient hospital facilities) was not available for analysis. Previous CDAD diagnosis was based on admission history only; stool toxin assay results were not required.

A symptom score was measured based on the presence or absence of weight loss, abdominal pain or nausea and/or vomiting. The presence of each symptom was given a score of one, and the total was summed; the maximum score was three.

If the patient had a previous CDAD diagnosis within the 60 days before admission, they were deemed to have recurrent CDAD. If a patient had more than one admission for CDAD, the last admission during the study period was analyzed. All antibiotic use within the 60 days before admission was counted regardless of duration of administration. Antibiotics were grouped by class (eg, cephalosporin, penicillin).

Comorbid diseases were divided into cardiovascular, pulmonary, renal, neurological and gastrointestinal organ systems; each organ system for which the patient had active disease was given a score of one as described previously (11). Other diseases that did not fit into organ systems (eg, diabetes) were grouped in a separate category (other) and scored similarly. If a patient had more than one active comorbidity in a given organ system (for example, lung cancer and viral pneumonia) the maximum score for that organ system remained one. Therefore, the maximum comorbidity score for a patient was six. Fever was defined as an oral temperature greater than or equal to $38^{\circ} \mathrm{C}$, and tachycardia as a heart rate 100 beats/min.

\section{Statistical analysis}

Differences between the means of continuous variables were assessed using Student's $t$-test, and ordinal variables were compared using the Mann-Whitney $U$ test. Differences in group proportions were analysed with the $\chi^{2}$ test, or the Fisher Exact test if sample sizes were less than five. For the evaluation of multiple risk factors on CDAD outcome, odds ratios were calculated using a forward stepwise logistic regression analysis using SPSS software (SPSS 6.1 for Windows; SPSS Inc., USA). Coefficients of the regression variables were tested for significance using differences of log likelihood statistics interpreted as $\chi^{2}$. Confidence intervals were calculated from the maximum likelihood estimates of the standard errors derived from the logistic models. Two-tailed tests of significance at the $\mathrm{P}<0.05$ level were used to determine statistical significance.

\section{RESULTS}

One hundred fifty-three patients met the selection criteria and were included within the analysis (Table 1). The mean age of patients was $63.4 \pm 20.5$ years, range 21 to 93 years. The majority $(64.7 \%)$ were female. Forty-four per cent of patients had community-acquired CDAD. Most patients were admitted to a general medicine ward.

Amongst all patients, the median number of antibiotics taken in the 60 days before admission was one (range zero to nine), with 17/153 (11.1\%) reporting no antibiotic exposure. Cephalosporins (60/153, 39.2\%), clindamycin (41/153, $26.8 \%)$, and fluoroquinolones $(37 / 153,24.2 \%)$ were the most common offending antibiotics (Table 2). Of the patients who had received metronidazole, vancomycin or aminoglycosides before developing CDAD, all had received other concomitant antibiotics as well; two patients received antineoplastic agents (cisplatin/etoposide and melphalan, respectively) without antimicrobial antibiotics.

\section{Univariate analysis}

There were 44/153 (28.8\%) patients who were classified as severe CDAD, of which 10/153 (6.5\%) died (Table 1). All the deaths appeared to be directly attributable to CDAD or its complications. The comparison of mild and severe CDAD groups is presented in Table 3. The severe CDAD group was significantly older than the mild CDAD patients (mean $74.1 \pm 13.9$ years versus $59.1 \pm 21.2$ years, $\mathrm{P}<0.001)$ and had more comorbid disease (median two major organ systems affected (range zero to five) versus one (range zero to four), 
TABLE 1

Patient demographics

\begin{tabular}{ll}
\hline & $\mathbf{n}(\%)$ \\
\hline Patients & 153 \\
Age (years) ${ }^{*}$ & $63.4 \pm 20.5$, range 21-93 \\
Female & $99(64.7)$ \\
& \\
Community-acquired CDAD & $68(44.4)$ \\
Hospital- or institutionally acquired CDAD & $85(55.5)$ \\
& \\
Admitting Service & $74(48.4)$ \\
Medicine (nongastrointestinal) & $26(17.0)$ \\
Gastrointestinal & $32(20.9)$ \\
Surgery & $21(13.7)$ \\
Family practice & \\
& $44(28.8)$ \\
Severe CDAD ${ }^{\dagger}$ & $32(20.9)$ \\
greater than 14 days admission & $7(4.6)$ \\
Colectomy & $5(3.3)$ \\
Intensive care unit & $10(6.5)$ \\
Died & \\
\hline
\end{tabular}

${ }^{*}$ mean $\pm S D$, range; ${ }^{\dagger}$ some patients met more than one criterion for severe $C D A D$. CDAD Clostridium difficile-associated diarrhea

$\mathrm{P}=0.001$ ). Additionally, patients diagnosed with recurrent CDAD were more likely to have severe CDAD (12/44 versus $10 / 109, \mathrm{P}<0.01$ ). The majority of patients in both the mild and severe CDAD groups had been institutionalized in the 60 days before admission (thus designated as hospital-acquired CDAD), either through residence in a nursing home or being an inpatient in hospital for over $24 \mathrm{~h}$; however, there was no significant proportional difference between the groups. There were no significant differences between the groups with respect to sex, number or type of antibiotics received, bowel movements per day, duration of symptoms, symptom score, admitting service or hospital.

In patients for which data were available, serum albumin level on admission was significantly lower in the severe group $(23.7 \pm 5.4 \mathrm{~g} / \mathrm{L}$ versus $27.2 \pm 7.8 \mathrm{~g} / \mathrm{L}, \mathrm{P}<0.05)$. Admission white blood cell count was higher and admission hemoglobin was lower in the severe CDAD group compared with the mild CDAD group, but the difference was not significant. There were no significant differences between the groups with respect to presence of fever or tachycardia on admission.

\section{Multivariate analysis}

Based on univariate analysis, four variables were identified that were significantly associated with severe CDAD: age over 70 years, increasing comorbid illness, recurrent $\mathrm{CDAD}$ and serum albumin level on admission. In multivariate analysis, risk factors for severe CDAD were the same: age over 70 years (OR 3.09, $\mathrm{P}<0.05)$, comorbid illness (OR 1.52, $\mathrm{P}<0.05)$ and recurrent $\mathrm{CDAD}(4.10, \mathrm{P}<0.01)$. Serum albumin was not entered into the logistic regression model due to excessive missing values.

The odds ratios for age over 70 years and comorbid illness from the multivariate model were slightly attenuated and less statistically significant compared with those from the univariate models. The odds ratios from the univariate and multivariate models for CDAD recurrence were similar in magnitude and significance.
TABLE 2

Antibiotic use in the 60 days before admission

\begin{tabular}{lll}
\hline Antibiotic & $\mathbf{n}$ & $\%$ \\
\hline Cephalosporin (all generations) & 60 & 39.2 \\
Clindamycin & 41 & 26.8 \\
Fluoroquinolone & 37 & 24.2 \\
Penicillin/ampicillin/amoxicillin & 23 & 15.0 \\
Aminoglycoside & 15 & 9.8 \\
Macrolide & 13 & 8.5 \\
Sulpha & 10 & 6.5 \\
Cloxacillin & 9 & 5.9 \\
Metronidazole & 7 & 4.6 \\
Vancomycin & 6 & 3.9 \\
Tetracycline & 4 & 2.6 \\
Nitrofurantoin & 1 & 0.7 \\
Antineoplastic agents & & 1.3 \\
None reported & 2 & 11.1 \\
\hline
\end{tabular}

*without antimicrobial antibiotic use

\section{DISCUSSION}

The clinical characteristics and risk factors for development of hospital-acquired CDAD are well established $(2,5-7,10,16,17)$. The risk factors and outcomes of community-acquired CDAD however, have been much less studied. Previous analyses have shown that most community-acquired CDAD has a benign clinical course, with very few patients needing hospital admission (12,18). A recent study from Sweden (19), however, suggests the incidence may be much higher than previously recorded. The environment of acquisition, as well as the outcomes and severity of cases that present to emergency departments have not been well described. In the present study, it was found that less than half of the patients presenting to emergency rooms with CDAD had the community-acquired disease.

The present study evaluated all patients who presented to hospital with CDAD. More than half had been in an institution such as a nursing home or hospital for more than $24 \mathrm{~h}$ in the 60 days before admission. Institutions are speculated to be reservoirs of $\mathrm{C}$ difficile $(20,21)$; although data on the timing of the administration of antibiotics with respect to institutionalization was not available in most cases, patients who were institutionalized were presumed to have hospital-acquired CDAD.

The reason for this presumption was a practical one, because exact temporal historical data is often difficult to elicit from a retrospective chart review. We felt this was a reasonable assumption to make, because the two key aspects of developing CDAD (acquisition of $\mathrm{C}$ difficile and administration of antibiotics) are both much more likely to occur in a hospital or nursing home. In this way we also were able to be reasonably sure that the patients we called community-acquired CDAD were, in fact, community-acquired.

In the present study, there was no significant difference between the community-acquired cases and institutionally acquired cases with respect to outcome, suggesting that the two act similarly when the disease is severe enough to warrant admission.

Specific strains of $\mathrm{C}$ difficile were not typed as a part of this study. During the study time period, diagnosis of CDAD was made by testing for $\mathrm{C}$ difficile toxin $\mathrm{A}$ in the stool. Although toxin A-negative strains were not thought to cause disease in 
TABLE 3

Univariate analysis of potential risk factors for severe Clostridium difficile-associated diarrhea (CDAD)

\begin{tabular}{|c|c|c|c|c|}
\hline & Mild CDAD ( $n=109)$ & Severe CDAD $(n=44)$ & OR $(95 \% \mathrm{Cl})$ & $\mathbf{P}$ \\
\hline Age (years; mean \pm SD) & $59.1 \pm 21.2$ & $74.1 \pm 13.9$ & $1.05(1.02-1.07)$ & $<0.001$ \\
\hline Age over 70 years & $47(43 \%)$ & $33(75 \%)$ & $3.96(1.81-8.63)$ & $<0.001$ \\
\hline Female sex & $72(66 \%)$ & $27(61 \%)$ & $0.90(0.63-1.30)$ & 0.58 \\
\hline Length of stay (days) ${ }^{*}$ & $6(1-13)$ & $17(2-92)$ & & $\mathrm{n} / \mathrm{a}$ \\
\hline Number of antibiotics (past 60 days)* & $1(0-9)$ & $1(0-4)$ & $0.76(0.54-1.08)$ & 0.13 \\
\hline Type of antibiotics (past 60 days) & - & - & & NS \\
\hline Hospital-acquired CDAD & $58(53 \%)$ & $27(61 \%)$ & $1.40(0.68-2.85)$ & 0.36 \\
\hline Symptom duration (days) ${ }^{*}$ & $6(1-35)$ & $6.5(1-45)$ & $1.03(0.99-1.06)$ & 0.16 \\
\hline Stools/ day (maximum)* & $7(1-30)$ & $6.5(0-45)$ & $0.99(0.93-1.05)$ & 0.72 \\
\hline Symptom score (out of 3 , range) & $1(0-3)$ & $1(0-3)$ & $0.83(0.55-1.23)$ & 0.35 \\
\hline Comorbid illness (organ systems)* & $1(0-4)$ & $2(0-5)$ & $1.83(1.27-2.65)$ & $<0.01$ \\
\hline CDAD recurrence (past 6 months) & $10(9 \%)$ & $12(27 \%)$ & $3.71(1.47-9.40)$ & $<0.01$ \\
\hline Fever $\left(>38^{\circ} \mathrm{C}\right)$ & $29(27 \%)$ & $8(18 \%)$ & $0.61(0.26-1.47)$ & 0.27 \\
\hline Tachycardia (>100 beats/min) & $42(39 \%)$ & $13(30 \%)$ & $0.68(0.32-1.45)$ & 0.32 \\
\hline WBC count $\left(\times 10^{9} / \mathrm{L} ;\right.$ mean $\left.\pm \mathrm{SD}\right)$ & $15.9 \pm 9.8$ & $18.3 \pm 12.2$ & $1.02(0.99-1.05)$ & 0.21 \\
\hline WBC greater than $15\left(\times 10^{9} / \mathrm{L}\right)$ & $81(53 \%)$ & $71(46 \%)$ & $1.55(0.77-3.15)$ & 0.22 \\
\hline Hemoglobin ( $g / L ;$ mean $\pm S D)$ & $121 \pm 19$ & $116 \pm 19$ & $0.99(0.97-1.01)$ & 0.16 \\
\hline $\operatorname{Albumin}^{\dagger}(\mathrm{g} / \mathrm{L} ;$ mean $\pm \mathrm{SD})$ & $27 \pm 8$ & $24 \pm 5$ & $0.93(0.86-1.00)$ & 0.04 \\
\hline Albumin less than $25 \mathrm{~g} / \mathrm{L}$ & & & $1.61(0.64-3.98)$ & 0.31 \\
\hline
\end{tabular}

${ }^{*}$ median (range); tresults available for 75 patients (40 in mild group and 35 in severe group). NS Not significant; n/a Not applicable; WBC White blood cell count

the past, recent reports have shown that these strains may also cause CDAD $(22,23)$. Therefore this study may have missed a small proportion of CDAD patients during the study period.

The most common types of causative antibiotics in the present study (cephalosporins, clindamycin and fluoroquinolones) are similar to those described in the literature $(5,7)$. It is possible that the introduction of broad spectrum oral cephalosporins with poor bioavailability have contributed to the apparent increase in community-acquired CDAD as suggested by Karlstrom (19). Unfortunately, due to the retrospective nature of the present study and the highly variable nature of historical documentation, we were unable to reliably document in some cases whether patients had received antibiotics as an outpatient or within an institution, or in oral versus parenteral forms; this aspect was therefore not analyzed. A significant proportion of patients $(11 \%)$ had no reported antibiotic exposure at all. Although this has been reported in other studies (24), it is likely that recall bias may account for some of these cases. There was also a small number of patients who had had previous metronidazole $(4.6 \%)$ or vancomycin $(3.9 \%)$ exposure before the development of CDAD. All of these cases had received concomitant antibiotics in the 60 days before admission.

Increased comorbid illness, age over 70 years and CDAD recurrence were found to be independent risk factors for a severe outcome in patients presenting to hospital with CDAD. The first two have been identified as risk factors in studies of hospital-acquired $\operatorname{CDAD}(9,10,19)$. Patients with significant comorbid illness or advanced age may not be as able to mount an effective immune response to the $\mathrm{C}$ difficile infection. Some studies have shown decreased levels of serum immunoglobulin $\mathrm{G}$ and immunoglobulin $\mathrm{A}$ antibodies to $\mathrm{C}$ difficile or its toxins in patients with symptomatic CDAD $(25,26)$.

CDAD recurrence was also shown to be a risk factor for a severe outcome. This finding is similar to a study by Fekety et al (27), where patients with recurrent CDAD were reported to have a higher frequency of severe colitis than those with an initial case of CDAD. The design of this study, however, did not allow for determining whether CDAD recurrence was due to relapse of a previously treated infection or a de novo infection occurring within the previous 60 days. Relapse is known to occur in $10 \%$ to $25 \%$ of cases treated with metronidazole or vancomycin $(5,7)$, possibly due to the sequestering of $\mathrm{C}$ difficile spores in colonic diverticulae, where they may not be flushed out by diarrhea or exposed to sufficiently high concentrations of antibiotic (28).

Mortality in this study was found to be $6.5 \%$, similar to series of hospital-acquired CDAD patients, which range from $4 \%$ (29) to $38 \%(4)$. The large variation in mortality in these studies appears to be due to the different patient populations; the former study included younger patients who underwent orthopedic surgery (mean age 55 years), whereas the latter study included older patients (over 60\% were over 65 years old) with considerable comorbidity.

Patients with CDAD sufficiently severe enough to require admission to hospital have similar outcomes to those who develop CDAD in hospital. Age over 70 years, comorbid illness and CDAD recurrence are risk factors for a poor outcome; extra vigilance should be taken with these patients to ensure aggressive early intervention. 


\section{REFERENCES}

1. Johnson S, Clabots CR, Linn FV, Olson MM, Peterson LR, Gerding DN. Nosocomial Clostridium difficile colonisation and disease. Lancet 1990;336:97-100.

2. McFarland LV, Mulligan ME, Kwok RY, Stamm WE. Nosocomial acquisition of Clostridium difficile infection. N Engl J Med 1989;320:204-10.

3. Mylonakis E, Ryan ET, Calderwood SB. Clostridium difficileassociated diarrhea: A review. Arch Intern Med 2001;161:525-33.

4. Anand A, Bashey B, Mir T, Glatt AE. Epidemiology, clinical manifestations, and outcome of Clostridium difficile-associated diarrhea. Am J Gastroenterol 1994;89:519-23.

5. Fekety R. Guidelines for the diagnosis and management of Clostridium difficile-associated diarrhea and colitis. American College of Gastroenterology, Practice Parameters Committee. Am J Gastroenterol 1997;92:739-50.

6. Kaatz GW, Gitlin SD, Schaberg DR, et al. Acquisition of Clostridium difficile from the hospital environment. Am J Epidemiol 1988;127:1289-94

7. Kelly CP, Pothoulakis C, LaMont JT. Clostridium difficile colitis. N Engl J Med 1994;330:257-62.

8. Cleary RK. Clostridium difficile-associated diarrhea and colitis: Clinical manifestations, diagnosis, and treatment. Dis Colon Rectum 1998;41:1435-49.

9. McFarland LV, Surawicz CM, Rubin M, Fekety R, Elmer GW, Greenberg RN. Recurrent Clostridium difficile disease: Epidemiology and clinical characteristics. Infect Control Hosp Epidemiol 1999;20:43-50

10. McFarland LV, Surawicz CM, Stamm WE. Risk factors for Clostridium difficile carriage and $\mathrm{C}$ difficile-associated diarrhea in a cohort of hospitalized patients. J Infect Dis 1990;162:678-84.

11. Ramaswamy R, Grover H, Corpuz M, Daniels P, Pitchumoni CS. Prognostic criteria in Clostridium difficile colitis. Am J Gastroenterol 1996;91:460-4

12. Hirschhorn LR, Trnka Y, Onderdonk A, Lee ML, Platt R. Epidemiology of community-acquired Clostridium difficile-associated diarrhea. J Infect Dis 1994;169:127-33.

13. Riley TV, Codde JP, Rouse IL. Increased length of hospital stay due to Clostridium difficile-associated diarrhoea. Lancet 1995;345:455-6.

14. Riley TV, Cooper M, Bell B, Golledge CL. Community-acquired Clostridium difficile-associated diarrhea. Clin Infect Dis 1995;20(Suppl 2):S263-5.

15. Riley TV, O'Neill GL, Bowman RA, Golledge CL. Clostridium difficile-associated diarrhoea: Epidemiological data from Western Australia. Epidemiol Infect 1994;113:13-20

16. Johnson S, Gerding DN. Clostridium difficile-associated diarrhea. Clin Infect Dis 1998;26:1027-34.
17. Johnson S, Homann SR, Bettin KM, et al. Treatment of asymptomatic Clostridium difficile carriers (fecal excretors) with vancomycin or metronidazole. A randomized, placebo-controlled trial. Ann Intern Med 1992;117:297-302.

18. Stergachis A, Perera DR, Schnell MM, Jick H. Antibioticassociated colitis. West J Med 1984;140:217-9.

19. Karlstrom O, Fryklund B, Tullus K, Burman LG. A prospective nationwide study of Clostridium difficile-associated diarrhea in Sweden. The Swedish C difficile Study Group. Clin Infect Dis 1998;26:141-5.

20. Clabots CR, Johnson S, Olson MM, Peterson LR, Gerding DN. Acquisition of Clostridium difficile by hospitalized patients: Evidence for colonized new admissions as a source of infection. J Infect Dis 1992;166:561-7.

21. Kim KH, Fekety R, Batts DH, et al. Isolation of Clostridium difficile from the environment and contacts of patients with antibioticassociated colitis. J Infect Dis 1981;143:42-50.

22. Alfa MJ, Kabani A, Lyerly D, et al. Characterization of a toxin A-negative, toxin B-positive strain of Clostridium difficile responsible for a nosocomial outbreak of Clostridium difficile-associated diarrhea. J Clin Microbiol 2000;38:2706-14.

23. Pituch $\mathrm{H}$, van den Braak N, van Leeuwen W, et al. Clonal dissemination of a toxin-A-negative/toxin-B-positive Clostridium difficile strain from patients with antibiotic-associated diarrhea in Poland. Clin Microbiol Infect 2001;7:442-6.

24. Marts BC, Longo WE, Vernava AM 3rd, Kennedy DJ, Daniel GL, Jones I. Patterns and prognosis of Clostridium difficile colitis. Dis Colon Rectum 1994;37:837-45.

25. Leung DY, Kelly CP, Boguniewicz M, Pothoulakis C, LaMont JT, Flores A. Treatment with intravenously administered gamma globulin of chronic relapsing colitis induced by Clostridium difficile toxin. J Pediatr 1991;118:633-7.

26. Mulligan ME, Miller SD, McFarland LV, Fung HC, Kwok RY. Elevated levels of serum immunoglobulins in asymptomatic carriers of Clostridium difficile. Clin Infect Dis 1993;16(Suppl 4):S239-44.

27. Fekety R, McFarland LV, Surawicz CM, Greenberg RN, Elmer GW, Mulligan ME. Recurrent Clostridium difficile diarrhea: Characteristics of and risk factors for patients enrolled in a prospective, randomized, double-blinded trial. Clin Infect Dis 1997;24:324-33.

28. Tedesco FJ, Gordon D, Fortson WC. Approach to patients with multiple relapses of antibiotic-associated pseudomembranous colitis. Am J Gastroenterol 1985;80:867-8.

29. Clarke HJ, Jinnah RH, Byank RP, Cox QG. Clostridium difficile infection in orthopaedic patients. J Bone Joint Surg Am 1990;72:1056-9. 


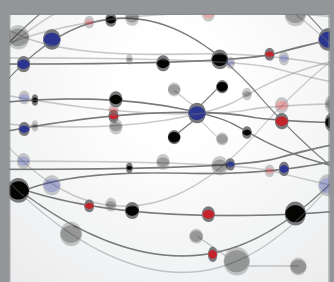

The Scientific World Journal
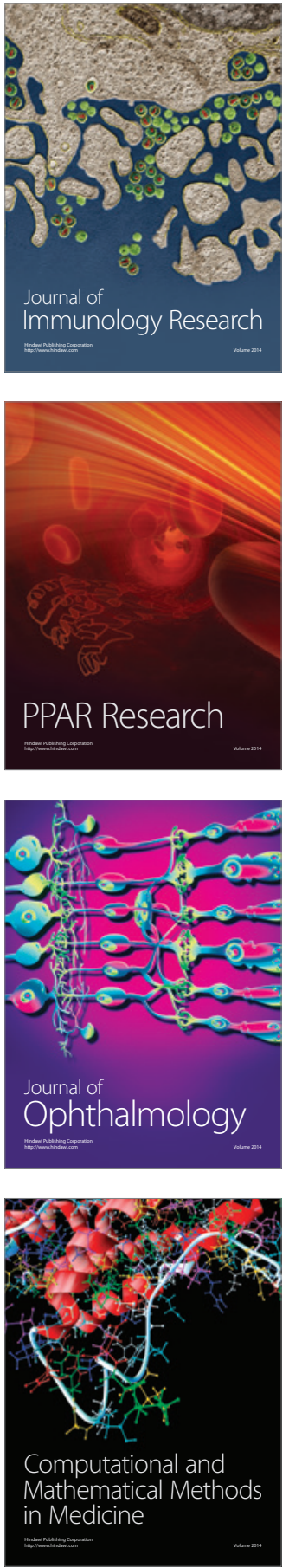

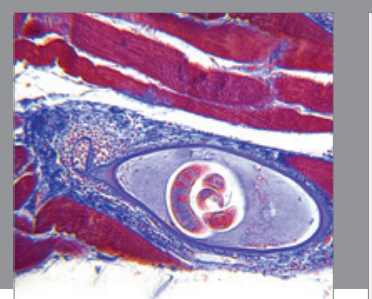

Gastroenterology Research and Practice

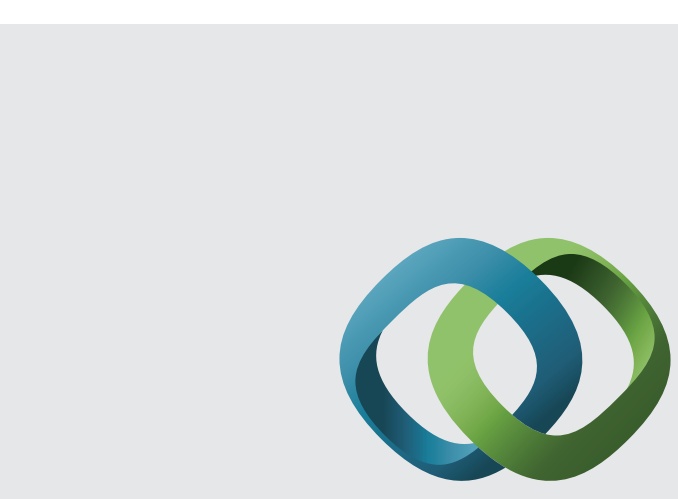

\section{Hindawi}

Submit your manuscripts at

http://www.hindawi.com
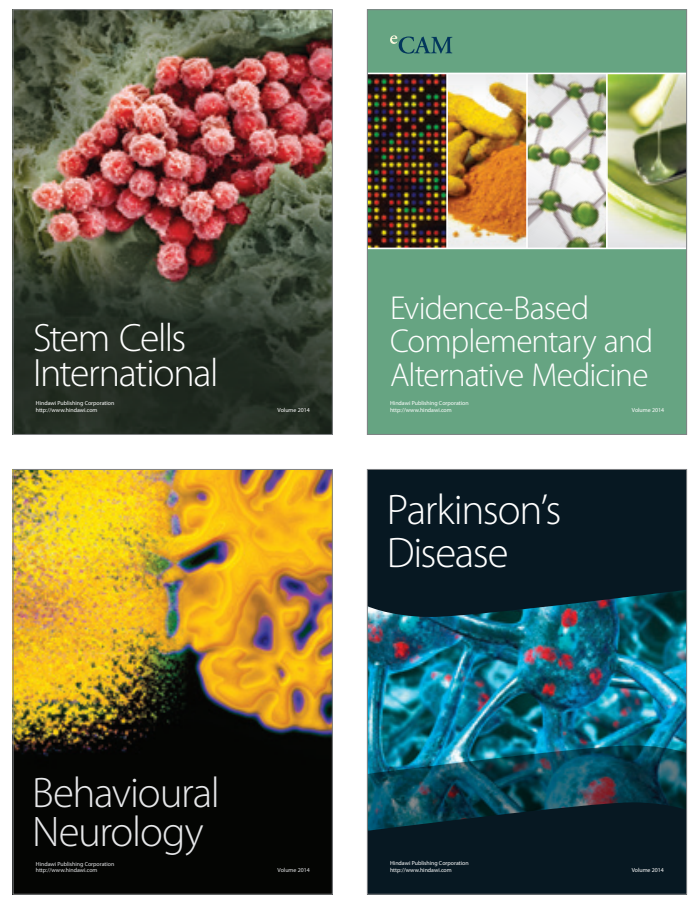
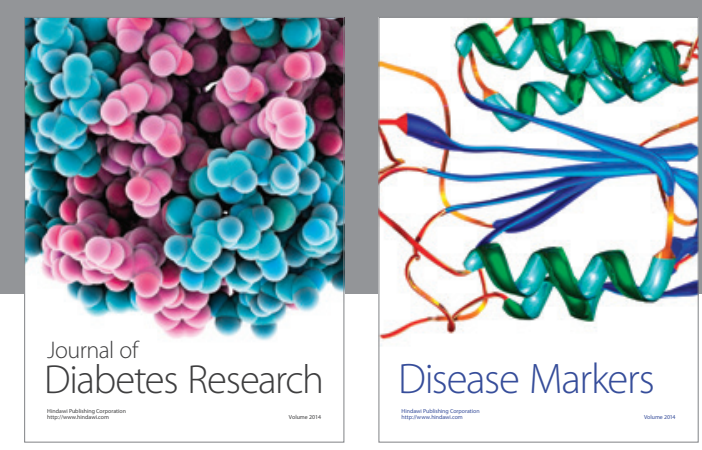

Disease Markers
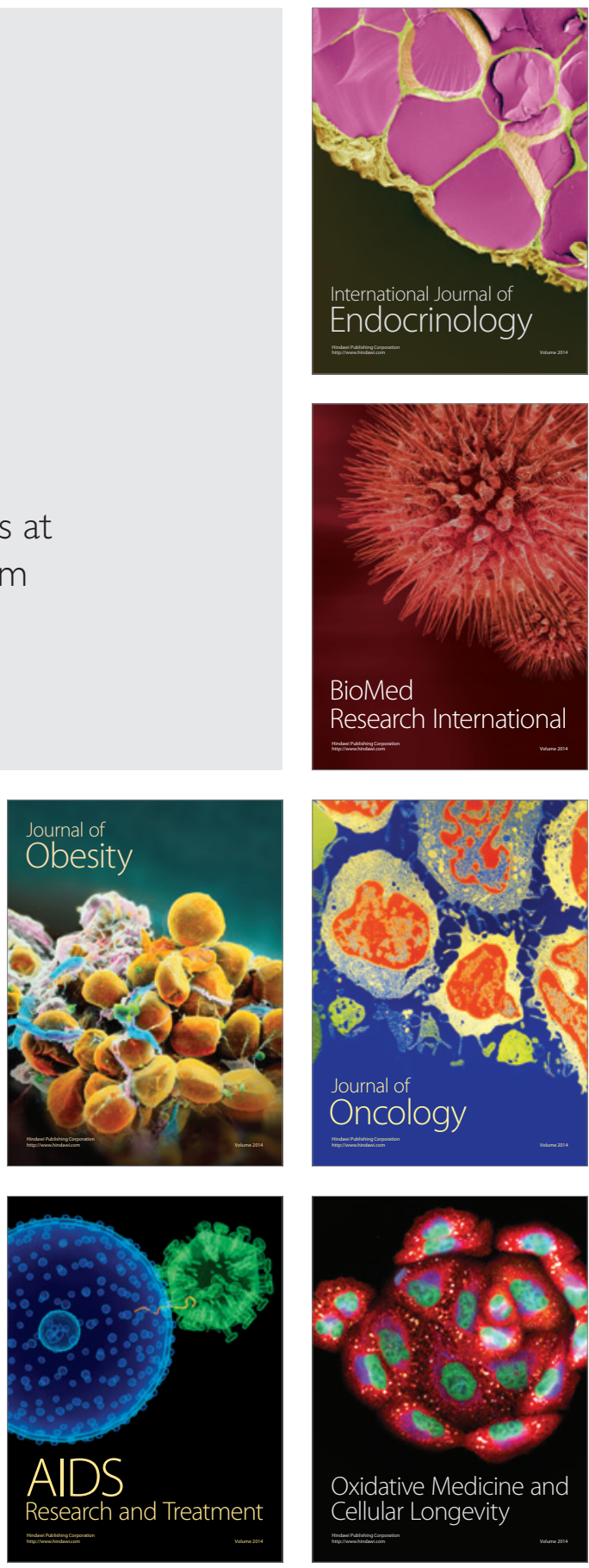